anales de psicología / annals of psychology

2019, vol. $35, \mathrm{n}^{\circ} 3$ (october), 424-433

http://dx.doi.org/10.6018/analesps.35.3.363501
(C) Copyright 2019: Editum. Servicio de Publicaciones de la Universidad de Murcia. Murcia (Spain) ISSN print edition: 0212-9728. ISSN on line edition (http://revistas.um.es/analesps): 1695-2294

On line edition License Creative Commons 4.0: BY-NC-ND

\title{
Classroom co-living climate: nature, measurement, effects and implications for social education. A cross-cultural study
}

\author{
Jesús Alonso-Tapia ${ }^{1, *}$, Cecilia Simón ${ }^{1}$, Nuria López-Valle², María A. Ulate ${ }^{2}$, and María L. Biehl \\ 1 Universidad Autónoma de Madrid (Spain) \\ 2 Ministerio de Educación Pública, (Costa Rica) \\ 3 Inter-American Development Bank - Education Division (Washington, DC, U.S.A.)
}

\begin{abstract}
Título: Clima de convivencia de clase: naturaleza, medida, efectos e implicaciones para la educación social. Un estudio transcultural.

Resumen: Este artículo tiene tres objetivos, después de proponer un modelo inicial de clima de convivencia en el aula: desarrollar dos medidas para probar su validez, probar su utilidad para analizar las diferencias entre las aulas y hacerlo en dos países diferentes. El modelo inicial incluye siete patrones de interacción que, si están presentes, favorecen la inclusión social de los estudiantes. El primer cuestionario evalúa el clima de clase percibido por el alumno y el segundo, el grado en que el alumno interactúa de acuerdo con el modelo. Los participantes fueron 2581 estudiantes de secundaria, 2038 de Costa Rica y 543 de España. Para probar el ajuste del modelo, se realizaron análisis factoriales confirmatorios, de validación cruzada y multigrupo. También se realizaron análisis de correlación y regresión para determinar la validez discriminante y concurrente utilizando como criterio una medida de integración social. Se utilizaron los análisis ANOVA para probar las diferencias entre las aulas $\left(\eta^{2}\right.$ entre .19 y .28). Los resultados, similares en ambos países, mostraron que ambos cuestionarios tenían una validez estructural adecuada (CFI entre .94 y .97), y una validez concurrente y discriminante $(r$ predictor-criterio entre .37 y $.44 ; p<.0001)$. Debido a la naturaleza de su contenido, los cuestionarios se pueden utilizar para planificar intervenciones dirigidas a mejorar la organización y evaluar su efica-
\end{abstract} cia.

Palabras clave: clima de aula; clima de convivencia; clima socioemocional; inclusión social; interacciones de los estudiantes.

\section{Introduction}

Students living together in a classroom can behave and interact in different ways that create a classroom living-together climate (Rosa, Fida \& Avallone, 2011) or, as we prefer to call it, a classroom coliving climate (CCC), as it is based on interactions between people sharing the same space. The term coliving is used mainly in contexts different from education such as "community arrangements" (Walker, 2017) -those arrangements allowing people to interact in the same space in ways that favor mutual acceptance, support and social integration and inclusion-. As mutual acceptance, support and social integration and inclusion are some of the classroom educational objectives, coliving can be used to refer to students' interactions in the classroom favoring the achievement of such objectives. The usefulness of the concept of "coliving climate", however, depends on identifying the main students' interactions patterns just referred to. If identified, teachers could favor the development of such patterns to avoid that emo-

* Correspondence address [Dirección para correspondencia]: Jesús Alonso-Tapia, Facultad de Psicología, Universidad Autónoma de Madrid, c/ Ivan Pavlov, 6, 28049-Madrid (Spain). E-mail: jesus.alonso@uam.es (Article received: 19-2-2019; revised: 11-3-2019; accepted: 2-6-2019)
Abstract: This paper has three objectives, after proposing an initial model of classroom coliving climate: to develop two measures to test its validity, to test their usefulness for analyzing differences between classrooms, and to do it in two different countries. The initial model includes seven interaction patterns that, if present, favor the students' social inclusion. The first questionnaire assesses the classroom coliving climate perceived by the student, and the second, the degree in which the student interacts according to the model. Participants were 2581 Secondary-School students, 2038 from Costa Rica and 543 from Spain. To test model-fit, confirmatory factor analyses, cross validation and multi-group analyses were carried out. Correlation and regression analyses were also carried out to determine discriminant and concurrent validity using as criteria a measure of social integration. ANOVA analyses were used to test for differences between classrooms $\left(\eta^{2}\right.$ between .19 and .28$)$. Results, similar in both countries, showed that both questionnaires had adequate structural validity (CFI between .94 and .97), and discriminant and concurrent validity ( $r_{\text {predictors-criterion }}$ between .37 and $.44 ; p<.0001)$. Due to the nature of their content, the questionnaires can be used for planning interventions aimed at improving coliving, and for assessing their effectiveness.

Keywords: classroom climate; coliving climate; socio-emotional climate; social inclusion; students' interactions.

tional difficulties, disruption, bullying and violence took place.

Given the negative consequences of the mentioned emotional and behavioral difficulties, educational researchers have often tried to identify which personal, classroom and school factors, as well as family factors contribute to the appearance and maintenance of such problems, and how to manage them once they have appeared, a try that implies a valuable effort (Furlong et al., 2012). However, instead of trying to identify which types of intervention favor the decrease of emotional and behavioral difficulties, the school -as "positive" institution- should work to favor the development of pro-sociality, cooperation, and social integration and inclusion. This is one of the aims of positive psychology. However, as stated by Kristjánsson (2012), there are questions about the effectiveness of positive education that need to be explored.

As stated above, positive coliving among students is reflected on specific interaction patterns that contribute to reciprocal acceptance and social inclusion of all students. However, which kinds of interaction patterns allow identifying whether the CCC in a particular classroom is positive and thus favor pro-sociality, cooperation and social inclusion? How the CCC can best be assessed to know whether CCC is positive or not? What are the effects of CCC on students' 
social inclusion? And, a previous question, which are the similarities and differences between the concept of CCC, and concepts such as classroom climate (CC) and classroom social climate (CSC)? The aim of our study is to give a possible answer to these questions from data gathered in two different countries. This aim implies to achieve three objectives after clarifying the conceptual relationship between CC, CSC and CCC, a task for which it will be necessary to develop a model of positive CCC that defines the main interaction patterns that configure it: a) to develop an instrument that allows assessing the perceived CCC, and to study its factorial, convergent and discriminant validity; b) to study its validity for predicting social inclusion, and c) to test the usefulness of the model and of the assessment instruments for determining differences between classrooms and their effects on social integration or inclusion.

Different authors that have studied classroom climate have shown that students not only are affected by and respond to each particular teacher's action, but also by the set of teacher's actions that define classroom climate (Ames, 1992; Evans, Harvey, Buckley \& Yan, 2009; Meece, Anderman \& Anderman, 2006). Therefore, it is important to identify the kinds of climate affecting student's behavior.

According to Evans et al. (2009), classroom climate is a multifaceted concept. It includes different dimensions: 1) the academic-instructional climate (AIC), defined by the pedagogical and curricular elements of the learning environment. 2) The disruption management climate (DMC), defined by the set of teacher's action patterns or strategies that show his/her particular style of preventing and solving discipline problems. 3) The "classroom emotional climate" (CEC), defined by the interactions that involve emotional exchange between teacher and student. Teacher's action patterns defining each dimension may have particular effects that deserve to be studied by themselves. In the motivational literature, other authors have used the concepts classroom motivational climate (CMC) (Ames, 1992) or the concept classroom goal structures (Meece et al., 2006) instead of academic-instructional climate to underline the motivational implications of this last facet of classroom climate. Finally, different authors have used the classroom social climate construct (Patrick, Kaplan \& Ryan, 2011), a multifaceted concept that includes different kinds of teachers' interaction patterns with their pupils -emotional support, academic support, task support and stress of mutual respect between students-, and that partially overlap with the concept "classroom emotional climate".

As can be seen, in all cases the term "climate" refers to the set of "teacher's" actions. However, these are not the only actions that affect students while working, behaving and interacting in the classroom. The set of predominant interactions between students "themselves" also exerts an important influence, as positive interactions between a student and their peers provides personal validation and emotional support, helps to solve problems, and to the development of perspective-taking and empathy, characteristics that serve as bases for cooperative, prosocial, and nonaggressive types of behavior (Wentzel, Russell \& Baker, 2014). Given this fact, if we want to promote the types of behavior referred, which are the kinds of specific interaction between students that may help to obtain such results, configuring thus a positive coliving climate?

After reviewing the relevant literature, it can be hypothesized that there are at least seven kinds of basic patterns of behavior in social interactions that, if generalized among the students in a classroom, could serve as initial indicators of a positive coliving climate. Probably they are not the only patterns that define this climate, but are a starting point for studying it. Such patterns are the following:

1) Active listening (Jones, 2011). If we reflect on the nature and process of social interactions, when a person wants to communicate something, the first thing that he/she wants is to be listened without interruptions and in an attentive way. Things being so, active listening, manifest in paraphrasing listened content and in reflecting feelings, contributes to the experience of being accepted and to the development of positive emotional ties between speaker and listener, as communication theorists have shown (Floyd, 2014). On the contrary, if students do not pay attention to their peers' talk, or if even interrupt them while speaking, then it is likely that interpersonal cohesion tends to break.

2) Trying to understand peers' point of view. It is frequent that students have points of view different from those of a peer. When it happens, students can act in at least two ways. On one side, students can paraphrase what the other student has said, asking for confirmation of own understanding to prevent misunderstandings, that is, students can try to understand their peers' points of view-, or can ask questions aimed at understanding the reasons of the discrepancy. On the other hand, they can oppose their own points of view to those of their peers without even trying to understand. In this last case, it is also frequent to see students scorning their peer's point of view. As already said, the first of the two ways of acting when discrepancy arises is an extension of active listening that can contribute to students' cohesion, as each peer can perceive the effort the other student is doing to understand the own position and to avoid any kind of scorn (Shotter, 2009).

3) Praise. Praise, or positive verbal reinforcement, has a positive influence in many aspects of academic and social learning "if it is perceived as sincere". Depending on the praised behavior, it encourages the attribution of performance to controllable causes, promotes autonomy, enhances competence without an overreliance on social comparisons, and conveys attainable standards and expectations (Henderlong \& Leeper, 2002). Given these conditions, it could be expected that children feel better in a context in which peers praise each other frequently and sincerely -pairing praise with experiences naturally reinforcing- (Owen, Smith \& Heyman, 2012). On the contrary, the lack of praise or even the presence of negative criticism directed to the person -not to the quality of 
a work -a kind of criticism that can be perceived as constructive feedback (Reynolds, 2009)- makes people to feel rejected and often moves them to react in an aggressive way. (Baron, 1988).

4) Helping others. Helping behavior is part of prosocial behavior, which has been defined as "voluntary behavior that benefits others or promotes harmonious relations with others" (e.g., providing emotional or practical help; Dovidio, Piliavin, Schroeder, \& Penner, 2006). Helping has usually been associated with friendship emergence, stability, and mutuality, implying a significant overlap between helping relations and friendships (Veenstra \& Dijkstra, 2011). However, some studies suggest that helping peers could be a selective process, being more likely among students to help others peers if they share some similarities, like grade of achievement or status (Rijsewijk, Dijkstra, Pattiselanno, Steglich, \& Veenstra, 2016).

5) Stand up for a victim. We should consider the relation between students' actions to defend a peer being scorned or bullied, and the classroom climate. Standing up for a victim of bullying is a powerful act that not only alleviates the distress of a victim, but also helps stop bullying behavior, even when just one person acts as a defender (Sainio, Veenstra, Huitsing, \& Salmivalli, 2010).

6) Emotional attention and support from peers. This characteristic appears when students in a group do not allow any peer to remain alone, isolated, and seems to depend on empathy (Olweus, 2001). The opposite would be to ostracize him or her. Research results show that emotional attention and support are associated with positive academic and social outcomes, providing students the sense that they can rely on others, and help to establish a sense of school belonging (Faircloth \& Hamm, 2005). Conversely, adolescents who do not perceive peers as supportive -those that are ostracized- often do not develop a strong sense of school belonging and may be at risk of poorer academic and social adjustment (Wentzel et al., 2014).

7) Group openness. Finally, a last aspect to consider, due to its potential influence in the coliving climate, is the flexibility within the groups of friends related to the interaction to the rest of the classmates that do not belong to them. In regards to group's interactions and friendship, it has been found that in early adolescence groups are more closed and less flexible, as they try to differentiate from the others groups. The loyalty to the group is an implicit rule, being usually disliked the friendships outside the group (Coleman \& Hendry, 2003). We could say the group sometimes acts as a cage. This tendency usually declines with age, but it results interesting to study to what extent the perception of this inflexibility in the group impact in the positive coliving with the rest of the classroom.

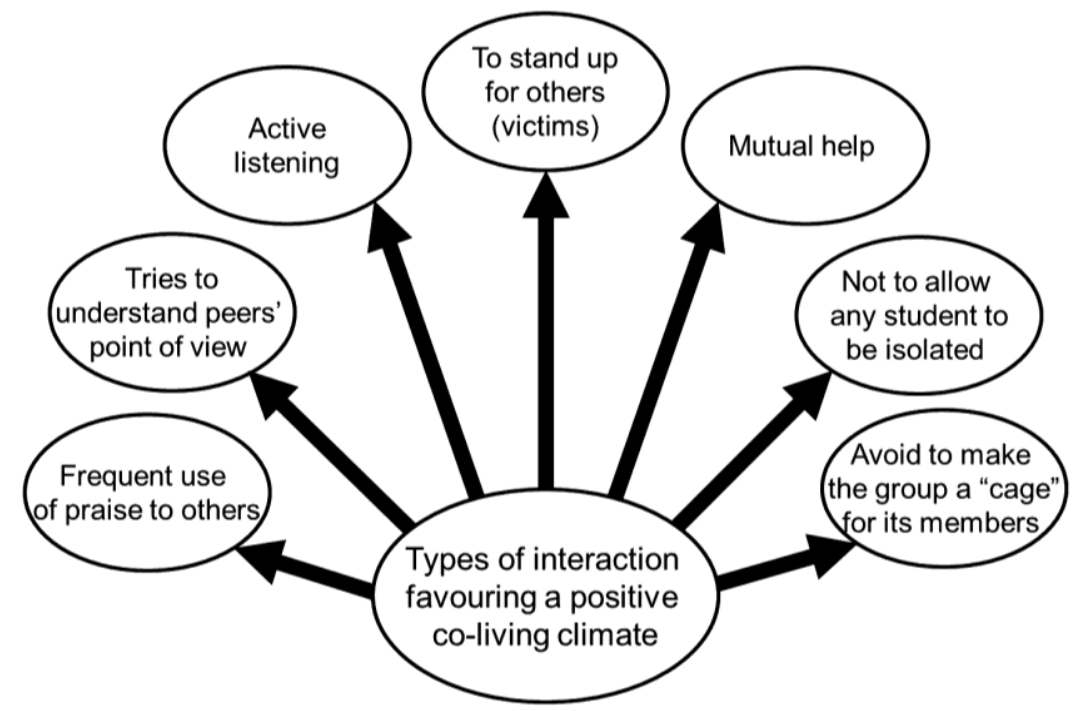

Figure 1. Hypothetical students' interaction patterns that configure the classroom coliving climate.

The interaction patterns just mentioned configure the classroom coliving model shown in Figure 1. As it has been advanced, such patterns are not the only ones favoring a positive coliving climate. However, they are a starting point for studying it. Therefore, it was decided to carry out this study with the following specific objectives: 1) to develop two measures to test the validity of the proposed coliving model, one for assessing the group coliving climate perceived by the student (GCC), and the other for assessing the degree in which the student considers that he/she interacts according to the model (SCC). The justification of developing two measures relies, first, on their different usefulness the first instrument can be useful for evaluating intervention programs addressed to groups of students, and the second for individual assessment and intervention-. Besides, the relationship between data coming from both sources can help to determine the degree in which the answers given to the CCG may depend on the student's personal perception of his/her 
own contribution to coliving. 2) To test their usefulness for detecting coliving climate differences between classrooms, and, 3) to test their cross-cultural validity, comparing data coming from two different countries. Objectives 2 and 3 are justified because knowing whether differences between classrooms and/or countries exist can help to adapt interventions aimed at improving CCC.

\section{Method}

\section{Participants}

A sample of 2581 Secondary-School students participated in the study. They belonged to two different countries, Costa Rica (CR) and Spain (SP). A total of 2038 students (998 females and 1040 males) from fourteen public schools formed the Costa Rican (CR) sub-sample. All schools were chosen by convenience reasons from different cities and towns of the country. Ages were comprised between 12 and 20 years $($ Mean $=14.98 ; S D=1.80)$. By educational level, 1058 belonged to the First Cycle of Secondary School (ages 11-15), 586 to the Second Cycle (ages 15-17) and 394 were High School or vocational training students (ages 17-20). As for the Spanish sub-sample (SP), a total of 543 students (246 females and 297 males) from three different public Secondary High Schools located in Extremadura (Spain) participated in the study. Two of the schools pertained to urban areas, and one, to a rural area. All of them were chosen by convenience reasons. Ages were comprised between 13 and 20 years
(Mean $=15.52 ; S D=1.25)$. By educational level, 42 belonged to the First Cycle of Secondary School (ages 11-15), 287 to the Second Cycle (ages 15-17) and 214 were High School students (ages 17-20).

\section{Instruments}

\section{Coliving climate questionnaires}

Two questionnaires were designed for this study. Both questionnaires are similar with one exception. The first one assesses the student's perception of the degree in which their peers use interaction strategies that favor a positive coliving climate (Group coliving climate questionnaire - GCCQ). The second, on its part, allows assessing the degree in which the student perceived that him/herself has and use such strategies (Student's contribution to coliving climate SCCCQ). Each questionnaire includes 21 items, three for each one of the seven strategies assessed: praise others achievements sincerely, active listening, trying to understand their peers' points of view, helping others, stand up for a peer, pay emotional attention to peers to avoid that they remain isolated, and prevent anyone from feeling imprisoned in the group. The degree of agreement with each item is assessed using 5-level Likert scales ranging from 1 (complete disagreement) to 5 (complete agreement). An example of items of each questionnaire is included in Table 1.

Table 1. Examples of Group coliving questionnaire (GCC) ${ }^{1}$

\begin{tabular}{ll}
\hline \multicolumn{1}{c}{ Variable assessed } & \multicolumn{1}{c}{ Item example } \\
\hline To praise others & My peers express admiration frequently when some student is successful or demonstrates ability \\
To try to understand others & When me peers do not understand me, they said it directly to my \\
To listen actively & In my classroom, the students interrupt me frequently. (-) \\
To stand up for a peer & In my classroom, if two students start fighting, most peers say or do something to stop the fight \\
To help others & In my classroom, if someone ask for help, it is not frequent to receive it, except from own friends (-) \\
To avoid that peers remain isolated & When we made a team, some peers remain always alone (-) \\
To prevent peers from feeling impris- & If someone of my group of friends starts making friends outside the group, be/ she usually receive negative criticism. \\
oned & $(-)$ \\
\hline Note: ${ }^{1}$ Items of the SCCC are similar, but referred to the own student.
\end{tabular}

Social integration questionnaire (Alonso-Tapia \& Rodriguez-Rey, 2012)

It is a questionnaire with a 12 -item single scale, six positively and six negatively worded. They allow assessing the degree of subjective social integration of the student, that is, the extent to which a student considers that: 1) he/she is accepted or rejected by his/her peer group, 2) his/her peers may ask or not for help if they need him/her, and 3) he/she would count on them or not. The degree of agreement with each item is assessed using 5-level Likert scales ranging from 1 (complete disagreement) to 5 (complete agreement). The original reliability of the scale was $\alpha=.80$. Examples of positive and negative items are: "My peers usually count on me to whatever they need" (positive) and "At school they speak badly about me behind my back" (negative).

\section{Procedure}

The development of the coliving questionnaires followed two steps. First, a previous work from Alonso-Tapia, Simón, López and Sandoval (2016) provided the bases for the questionnaires. It included the first five of the seven categories of the new questionnaire. The two new scales were derived from a small open survey realized to 25 Secondary students and from the reviewed literature. The questionnaires were first developed by Spanish researchers. Later, adaptation to idiomatic peculiarities of CR were carried out by CR experts and then discussed with Spanish researchers before the changes were accepted. 
All participating schools, parents and students gave their informed consent. Students filled in the questionnaires in 30minute sessions, distributed into the groups and courses to which they belonged. One of the researchers, present during the sessions, provided participants with precise instructions on how to fill in the questionnaires.

\section{Data analysis}

To determine the factorial and concurrent validity of the two questionnaires, before analyzing data, the answers to items assessing each of the interaction strategies were grouped in parcels after testing whether correlations between the three items of each parcel were as expected. Item parcels were used since this procedure has well known advantages such as fewer parameters to estimate and fewer chances for residuals to be correlated or dual loadings to emerge (MacCallum, Widaman, Zhang, \& Hong, 1999), and so, it allows to specify a clear latent construct (Little, Cunningham, Shahar, \& Widamar, 2002), which provides a simpler and potentially more useful interpretation. Parcels defined the variables used in the analysis. Then, after dividing the CR sample randomly in two subsamples for cross-validation, the following analyses were carried out.

\section{Confirmatory factor analyses (CFA)}

In a first step, data from CR were analyzed. The structure suggested originally by Alonso-Tapia, Simón, López and Sandoval (2016) was used as baseline model. This structure assumed the existence of only one factor on which all the observed variables would load. Two CFA were realized, one for the Positive coliving climate questionnaire (CFA1: GCC_CR), and the other for the Student's contribution to coliving climate questionnaire (CFA4: SCCC_CR). For these analyses, only the first subsample was used. Confirmatory factor analysis estimates were obtained using the maximum likelihood method, after examining whether data were adequate for the analysis (Mardia coefficient for GCC: $17.33<$ 70, and for SCCC: $9.09<.70)$; (Rodríguez \& Ruiz, 2008). In order to assess model-fit, absolute fit indexes $\left(\chi^{2}, \chi^{2} / d f\right.$, GFI, SRMR), incremental fit indexes (TLI) and non-centrality fit indexes (CFI, RMSEA) were used, as well as criteria for acceptance or rejection based on the degree of adjustment suggested by Hair, Black, Babin and Anderson (2010): $\chi^{2} / d f<5$; GFI, IFI and CFI > .90; RMSEA < .08; SRMR <.08). AMOS 24 was used for analyzing data.

\section{Multi-group cross-validation analyses}

Two multi-group confirmatory factor analyses were performed, one for cross validating the structure of each questionnaire (CFA2: GCC_CR and CFA5: SCCC_CR), using both the estimation and validation subsamples, and imposing different sets of restrictions of parameter equality. The estimation method, adjustment indexes and criteria for acceptance or rejection were the same as those for the CFA1.

\section{Multi-group analyses by country}

With the aim of testing whether "country" had a significant effect on data adjustment to the theoretical structure proposed, two multi-group analysis by country were carried out, using the whole sample from each country (CFA3: GCC-CR/SP and CFA6: SCCC-CR/SP). In both cases, the estimation method, adjustment indexes and criteria for acceptance or rejection were the same as in previous analyses.

\section{Reliability analyses}

McDonald's $\omega$ (McDonald, 1999) was used for analyzing the reliability of the scales of each questionnaire.

\section{Correlation analyses}

With the aim of gathering initial information on the convergent, discriminant and criterial validity of each questionnaire, correlation between the general scales of each questionnaire and between these scales and the score on social integration were calculated and analyzed. In order to have evidence of convergent validity, according to Hair (2014), correlation should be equal to or greater than $.70\left(\mathrm{R}^{2} \geq .50\right)$. As for discriminant validity, the criterion proposed by Forner \& Lacker (1981) and accepted by Hair (2014) was used. According to such criterion, there are discriminant validity if the square root of the average variance extracted (AVE) is greater than the square of the correlation between the constructs with which it is compared.

\section{Regression analyses}

Finally, for determining the criterion validity, two regression analyses were realized, one for each country. In these analyses the scores in both questionnaires were used as predictors and the score in the social integration questionnaire was used as criterion.

\section{ANOVA analyses}

In order to test whether CCC differs between classrooms and whether differences are related with differences at the group level in social integration, first, ANOVA of measures in GCC, SCCC and SI were carried out, and then, correlations between classroom means in each variable were calculated.

\section{Results}

\section{Descriptive analyses}

Table 2 shows means and standard deviations of each variable of GCC, SCCC. 
Table 2. Means ad standard deviations of GCC and SCCC variables.

\begin{tabular}{lcccc}
\hline & \multicolumn{2}{c}{ Group Coliving Climate } & \multicolumn{2}{c}{ Subject contribution to coliving climate } \\
\cline { 2 - 5 } \multicolumn{1}{c}{ Variables } & Mean & $S D$ & Mean & $S D$ \\
\hline Praise & 8.57 & 3.18 & 10.19 & 2.65 \\
Trying to understand & 9.34 & 2.64 & 11.05 & 2.70 \\
Active listening & 9.31 & 2.91 & 11.39 & 2.69 \\
Stand up & 9.03 & 2.73 & 9.95 & 2.90 \\
Helping others & 10.58 & 2.49 & 12.25 & 2.58 \\
No isolation & 9.41 & 3.25 & 10.38 & 2.54 \\
Group flexibility & 10.60 & 2.65 & 11.27 & 2.63 \\
\hline & & 11.70 & 76.49 & 11.06
\end{tabular}

\section{Group Coliving Climate questionnaire}

\section{GCC-CR Initial confirmatory factor analysis (CFA1)}

Figure 2 shows the standardized estimates of the confirmatory model. All estimated weights $(\lambda)$ are significant $(p$ $<0.001)$. Besides, Table 3 shows the fit statistics obtained for the proposed model (CFA1). As it can be seen, the statistic $\chi^{2}$ is significant probably due to sample size, but the ratio $\chi^{2} / d f$ and the remaining fit indexes are well inside the limits that allowed the model to be accepted.

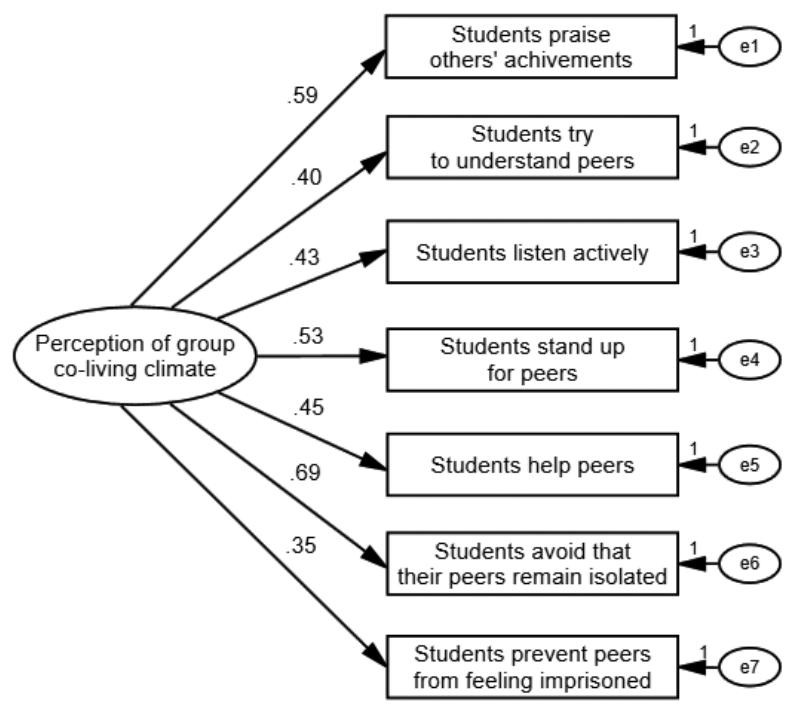

Figure 2. CFA1. Initial confirmatory model of the Group Co-living climate questionnaire (GCC).

Table 3. Questionnaires GCC ${ }^{1}$ and SCCC 2 . Goodness of fit of confirmatory, cross validation and multi-group analyses by country of the basic model.

\begin{tabular}{|c|c|c|c|c|c|c|c|c|c|}
\hline Questionnaire GCC & $\chi^{2}$ & $d f$ & $p$ & $\chi^{2} / d f$ & GFI & TLI & CFI & RMSEA & SRMR \\
\hline $\begin{array}{l}\text { CFA1 (GCC-CR } 3 \text { ) } \\
(\mathrm{N}=1019)\end{array}$ & 38.64 & 14 & .001 & 2.76 & .99 & .96 & .97 & .04 & .02 \\
\hline $\begin{array}{l}\text { CFA2-CV (GCC-CR) } \\
(\mathrm{N}=1019 / 1019)\end{array}$ & 98.64 & 35 & .001 & 2.82 & .99 & .96 & .96 & .03 & .03 \\
\hline $\begin{array}{l}\text { CFA3 (SCCC- CR/SP) } \\
(\mathrm{N}=543 / 2038) \\
\text { Questionnaire SCCC }\end{array}$ & 150.18 & 28 & .000 & 5.36 & .98 & .92 & .95 & .04 & .03 \\
\hline $\begin{array}{l}\text { CFA4 (SCCC-CR) } \\
(\mathrm{N}=1019)\end{array}$ & 60.52 & 14 & .001 & 4.32 & .98 & .91 & .94 & .05 & .03 \\
\hline $\begin{array}{l}\text { CFA5-CV (SCCC-CR) } \\
(\mathrm{N}=1019 / 1019)\end{array}$ & 159.19 & 42 & .001 & 3.79 & .98 & .92 & .92 & .03 & .03 \\
\hline $\begin{array}{l}\text { CFA6 (GCC-CR/SP4) } \\
(\mathrm{N}=543 / 2038)\end{array}$ & 135.59 & 28 & .000 & 4.84 & .99 & .93 & .95 & .04 & .03 \\
\hline
\end{tabular}

Notes: ${ }^{1}$ GCC: Group coliving climate; ${ }^{2}$ SCCC: Subject contribution to coliving climate; ${ }^{3}$ CR: Costa Rica; ${ }^{4}$ SP: Spain.

\section{GCC-CR Cross validation analysis (CFA2)}

In this analysis all weights $(\lambda)$ are significant $(p<0.001)$. Fit indexes (Table 3 ) show that the statistic $\chi^{2}$ is significant probably due to sample size, but the ratio $\chi^{2} / d f$ and the remaining fit indexes are well inside the limits that allowed the model to be accepted. Besides, as shown in Table 4, results of group comparison show that fit does not decrease if restrictions of equality between parameters are imposed for measurement weights and structural covariances. Therefore, the model is well estimated. 
Table 4. Cross validation analyses of the basic model of questionnaires GCC $^{1}$ and SCCC ${ }^{2}$, and multi-group analyses by country. Differences in $\chi^{2}$ in model comparisons with restrictions against the model without restrictions of parameter equality.

\begin{tabular}{|c|c|c|c|c|}
\hline Analyses & Model comparison & $\chi^{2}$ & $d f$ & $p$ \\
\hline \multirow{3}{*}{$\begin{array}{l}\text { CFA2-CV (GCC- CR } 3 \text { ) } \\
(\mathrm{N}=1019 / 1019)\end{array}$} & Measurement weights & 10.86 & 6 & .09 \\
\hline & Structural covariances & 11.54 & 7 & .12 \\
\hline & Measurement residuals & 31.77 & 14 & .00 \\
\hline \multirow{3}{*}{$\begin{array}{l}\text { CFA3-CV (GCC-SP4/CR) } \\
(\mathrm{N}=543 / 2038)\end{array}$} & Measurement weights & 19.43 & 6 & .00 \\
\hline & Structural covariances & 22.59 & 7 & .00 \\
\hline & Measurement residuals & 66.47 & 14 & .00 \\
\hline \multirow{3}{*}{$\begin{array}{l}\text { CFA5-CV (SCCC-CR) } \\
(\mathrm{N}=1019 / 1019)\end{array}$} & Measurement weights & 4.60 & 6 & .60 \\
\hline & Structural covariances & 4.65 & 7 & .70 \\
\hline & Measurement residuals & 18.07 & 14 & .20 \\
\hline \multirow{3}{*}{$\begin{array}{l}\text { CFA6-CV (SCCC-SP/CR) } \\
(\mathrm{N}=543 / 2038)\end{array}$} & Measurement weights & 34.55 & 6 & .00 \\
\hline & Structural covariances & 49.30 & 7 & .00 \\
\hline & Measurement residuals & 144.59 & 14 & .00 \\
\hline
\end{tabular}

Note: ${ }^{1}$ GCC: Group coliving climate; ${ }^{2}$ SCCC: Subject contribution to coliving climate; ${ }^{3}$ CR: Costa Rica; ${ }^{4}$ SP: Spain. ${ }^{5}$

\section{GCC Multi-group analysis by country (CFA3)}

In this analysis all weights $(\lambda)$ are significant $(p<0.001)$. Fit indexes (Table 3) show that the statistic $\chi^{2}$ is significant, probably due to sample size, but the ratio $\chi^{2} / d f$ and the remaining fit indexes are well inside the limits that allowed the model to be accepted. Therefore, the model is well estimated. However, as shown in Table 4, results of group comparison show that fit decreases significantly if restrictions of equality between parameters are imposed for measurement weights, structural covariances and measurement residuals. This fact implies that, though the model is well estimated, there are significant differences in the degree to which each variable loads on the latent factor for each group of students according to their country.

In order to know which variables are responsible of loading differences found between the two countries, it was decided to calculate the statistic $Z$ of Clogg, Petkova and Haritou (1995) to test which differences between regression weights are significant. The result of this analysis appears in Table 5. It shows that in all cases in which differences are significant $(Z \geq 1.96)$, their degree of contribution to coliving climate is grater in Spain than in Costa Rica.

Table 5. Group Coliving Climate (GCC). Differences between regression weights corresponding to Multi-group analysis by Country.

\begin{tabular}{|c|c|c|c|}
\hline Variables & Beta Costa Rica & Beta Spain & Z-Clogg \\
\hline To praise others & 1.64 & 1.24 & .41 \\
\hline To try to understand others & .62 & .77 & -1.39 \\
\hline To listen actively & .61 & .80 & -1.50 \\
\hline To stand up for a peer & 1.14 & 1.55 & -2.27 \\
\hline To help others & .48 & .80 & -2.53 \\
\hline To avoid that peers remain isolated & .54 & .97 & -3.48 \\
\hline To prevent peers from feeling imprisoned & .81 & .97 & -1.26 \\
\hline
\end{tabular}

\section{Student's contribution to coliving climate Question- naire}

\section{SCCC-CR Initial confirmatory factor analysis (CFA4)}

Figure 3 shows the standardized estimates of the confirmatory model. All estimated weights $(\lambda)$ are significant $(p$ $<0.001)$. Besides, Table 3 shows that all fit statistics obtained for the proposed model (CFA3) are well inside the limits that allowed the model to be accepted.

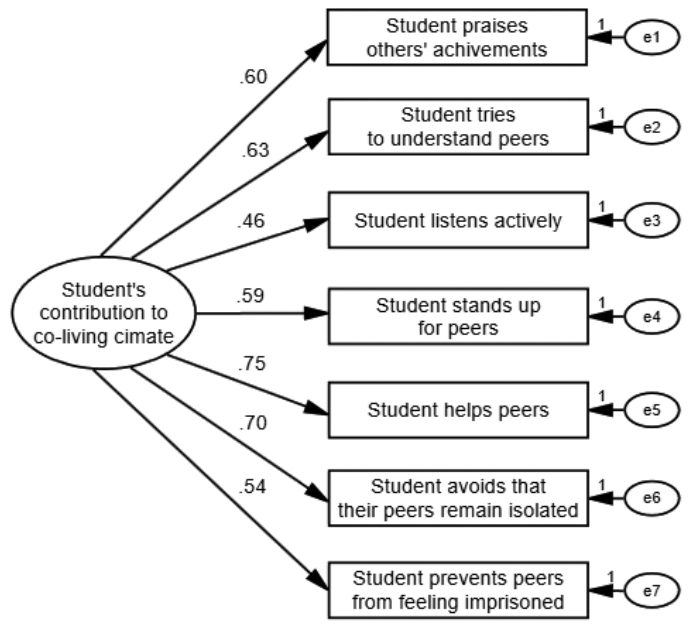

Figure 3. Initial confirmatory model of the student's contribution to coliving climate questionnaire (SCCC). 


\section{SCCC-CR Cross validation analysis (CFA5).}

In this analysis all estimated weights $(\lambda)$ are also significant $(p<0.001)$. Table 3 shows that all fit statistics obtained for the proposed model (CFA5) are well inside the limits that allowed the model to be accepted. Besides, as can be seen in Table 4, results of group comparison show that fit does not decrease significantly even if restrictions of equality between parameters are imposed for measurement weights, structural covariances and measurement residuals. Therefore, the model is well estimated.

\section{SCCC Multi-group analysis by country (CFA6).}

In this analysis all weights $(\lambda)$ are significant $(\phi<0.001)$. Fit indexes (Table 3 ) show that the statistic $\chi^{2}$ is significant probably due to sample size, but the ratio $\chi^{2} / d f$ and the remaining fit indexes are well inside the limits that allowed the model to be accepted. Therefore, the model is well estimated. However, as shown in Table 4, results of group comparison show that fit decreases significantly if restrictions of equality between parameters are imposed. This fact implies that, though the model is well estimated, there are significant differences in the degree to which each variable loads on the latent factor for each group of students according to their country.

In order to know which variables are responsible of loading differences found between the two countries, it was decided to calculate the statistic Z of Clogg, Petkova and Haritou (1995) to test which differences between regression weights are significant. The result of this analysis appears in Table 6. It shows that in all cases in which differences are significant $(Z \geq 1.96)$-trying to understand others, belping others, avoiding peers to remain isolated and preventing peers from feeling imprisoned- their degree of contribution to coliving climate is grater in Spain than in Costa Rica.

Table 6. Student contribution to Coliving Climate (SCCC). Differences between regression weights corresponding to Multi-group analysis by Country.

\begin{tabular}{lccc}
\hline Variables & $\begin{array}{c}\text { Beta Costa } \\
\text { Rica }\end{array}$ & $\begin{array}{c}\text { Beta } \\
\text { Spain }\end{array}$ & Z-Clogg \\
\hline To praise others & 1.17 & 1.05 & .83 \\
To try to understand others & .56 & 1.12 & -4.63 \\
To listen actively & .84 & .95 & -.91 \\
To stand up for a peer & .99 & 1.18 & -1.52 \\
To help others & 1.01 & 1.41 & -2.98 \\
To avoid that peers remain isolated & .89 & 1.12 & -2.06 \\
To prevent peers from feeling im- & .61 & 1.02 & -3.67 \\
prisoned & & & \\
\hline
\end{tabular}

\section{Reliability}

The general scales of both questionnaires -GCC and SCCC- are very reliable according to McDonald's $\omega$ indexes. The indexes were, in the Costa Rican Sample: $\omega_{\mathrm{GCC}}=.85$; $\omega_{\text {SCCC }} .91$, and in the Spanish sample: $\omega_{\mathrm{GCC}}=.94 ; \omega_{\mathrm{SCCC}}: .96$. As for the reliability of the Social Integration Questionnaire, the indexes were, in the Costa Rican sample: $\omega_{\mathrm{SIQ}}=.78$, and in the Spanish sample: $\omega_{\mathrm{SIQ}}=.77$.

\section{Correlation analyses}

To determine convergent and discriminant validity, that is, whether GCC and SCCC measure the same or different constructs, $r$ GCC-SCCC was calculated. The result does not fit to the criterion proposed by Hair $\left(R^{2} \geq .50\right)$ for convergent validity neither in CR nor in Spain (CR: $R^{2}$ GCC-SCCC $=.36$; Spain: $R^{2}$ GCC-SCCC $\left.=.17\right)$. This fact supports the initial supposition according to which they do not measure the same variables. Though the scales of both questionnaires have the same names because they refer to the same behaviors, the degree in which a student perceives the assessed behaviors in the group does not have to be the same as the degree in which he/she shows the same behaviors.

Besides, if we consider the same result from the point of view of discriminant validity, $\mathrm{R}^{2}$ between the two constructs is clearly lower than the square root of the mean variance extracted for each of them for both countries (Spain: $\sqrt{ }$ AVE GCC: $\sqrt{ } .393=.627 ; \sqrt{ }$ AVE sCC: $\sqrt{ } .485=.697$. CR: $\sqrt{ }$ AVE GCC: $\sqrt{ } .251=.501 ; \sqrt{ }$ AVE sCCC: $\sqrt{ } .234=.484)$. This fact implies that both constructs are clearly different.

In the same way, both constructs are different from the construct social integration (SI). The $\mathrm{R}^{2}$ of each of the two constructs with SI in both countries (Spain: $r^{2}$ GCC-SI $=.13 ; r^{2}$ SCCC-SI $=.19 ;$ CR: $r^{2}$ GCC-SI $=.18 ; r^{2}$ SCCC-SI $\left.=.144\right)$ is clearly lower than the square root of the mean variance extracted for each construct just described. However, the correlations of GCC and SCCC with SI, though moderated, are positive and significant in both countries as expected (CR: $r$ GCC-SI $=$ $.40 ; r_{\mathrm{SCCC}-\mathrm{SI}}=.38$; Spain: $\left.r_{\mathrm{GCC}-\mathrm{SI}}=.37 ; r_{\mathrm{SCCC}-\mathrm{SI}}=.44\right)$, a fact that implies that the behaviors assessed by both questionnaires contribute to social integration.

\section{Regression analyses}

As both questionnaires -GCC and SCCC- relate significantly with SI, two regression analyses were realized in order to know the relative weight of GCC and of SCCC as predictors of SI. The direct method was used. In the case of CR, the results were: $R^{2}=.18$, and the standardized weights: CCG: $.28, \mathrm{p}<.001$, SCCC: $.19, p<.001)$, and in the case of SP: $R^{2}=.24$, and the standardized weights: CCG: $.22, p<$ .001 , SCCC: $.34, p<.001)$. Though both predictors have a positive and significant weight in both countries, CCG seems to be a best predictor of SI for CR students, and SCCC, for SP students.

\section{ANOVA analyses}

Result of ANOVA of differences between classrooms y GCC were highly significant $\left(F_{\text {(df: } 124,2018)}=5.88, p<.0001\right.$, 
$\left.\eta^{2}=.28\right)$. The same happened with $\operatorname{SCCC}\left(\mathrm{F}_{(\mathrm{df}: 124,2018)}=\right.$ $\left.3.54, p<.0001, \eta^{2}=.19\right)$, and with SI $\left(F_{\text {(df: } 124,2018)}=3.90, \mathrm{p}\right.$ $\left.<.0001, \eta^{2}=.20\right)$. As for correlations analyses between the means of each group in these variables (GCC-SCCC $=.82$; GCC-SI $=.65$; SCCC-SI $=.68$; in all cases, $p<.0001)$.

\section{Discussion and conclusion}

Tis paper introduced the concept of classroom coliving climate (CCC). It refers to the positive or negative quality of relations among students assessed on the base of the types of behaviors that make possible such quality. In the theoretical section, the differences between this and related concepts were analyzed. It differs from the most general concept classroom climate, that includes the components of classroom academic-motivational climate, classroom disruption management, and classroom emotional climate, and that refers only to the effect of teachers' behavior patterns that configure such climates. The same happens with the concept of classroom social climate, a concept that overlaps in some degree with the concept of classroom emotional climate. The importance of CCC strives on the fact that, depending on its nature, it can favor social integration, that is an educational objective of paramount importance. Therefore, according to the studies reviewing such quality, it was proposed an initial model according to which, CCC could depend on the degree in which students adopt regularly at least seven behavior patterns: to praise others achievements sincerely, to listen actively, to try to understand their peers' points of view, to help others, to stand up for their peers, to pay emotional attention to peers avoiding their isolation, and to prevent anyone from feeling imprisoned in the group. In relation to the proposed classroom coliving model, this paper had three main objectives.

The first was to devise instruments for assessing the CCC that were useful for determining its quality and for guiding educational interventions, and to test their validity. In relation to this objective, this study has shown that the two questionnaires developed, the GCC and the SCCC, have very good factorial and discriminant validity, and that the structure of both generalizes between groups and countries. Besides, individual scores in both questionnaires contribute with a significant weight to predict the degree of students' social integration, that is, the degree in which they consider that are respected by their peers and not subjected to isolation or bullying behaviors. These results imply that, in order to favor the creation of a good coliving climate, it is important not only to pay attention to the group as a whole, but also to each individual student, as he/she can need specific help to acquire the social competencies that contribute to coliving climate.

The second objective was to test the existence of differences between classrooms. Both questionnaires allow to de- tect significant differences between groups. These differences are positively and highly related to differences in the degree of social integration of each group. It cannot be said that it is a causal relation, as evidence come from correlations, but the results allow to hypothesize it.

The third objective was to test for differences between countries. In this case, the comparison has shown, in the case of GCC, that to stand up for a peer, to help others and to avoid peers to remain isolated are best indicators of coliving climate in Costa Rica that in Spain, and in the case of SCCC, that to try to understand others, to help others, to avoid peers to remain isolated and to prevent peers from feeling imprisoned are best indicators in Spain that in Costa Rica of the degree in which students consider that they contribute to coliving climate. These differences should be taken into account when designing intervention programs aimed at improving coliving. Though intervention programs should favor the acquisition of all the behavior patterns that configure the coliving climate, they should stress the development of the patterns more valued in each socio-cultural context.

Our results have theoretical and practical implications. From a theoretical point of view, they expand the concept of classroom climate, based on teachers' behaviors (Evans et al., 2009; Sriklaub, Wongwanicich \& Wiratchai, 2015), by including a new facet of it based on the quality of students' specific interactions. This consideration points to the need of exploring the relation between both types of component of CCC, teachers' behaviors and students' specific interactions. As for the practical implications, the fact that the basis of both questionnaires are well-defined interaction strategies opens the possibility of using the results of assessment for two purposes: a) for designing group and individual intervention programs aimed at favoring the acquisition of them as a part of the task of favoring social inclusion, and b) for assessing the quality and degree of changes produced by such interventions -whether acquiring such interaction modes favors social inclusion or not-. In fact, the meta-analyses of Durlak, Weissberg, Dymnicki, Taylor and Schellinger (2011) and of Voight and Nation (2016) point in this direction.

This study has some limitations. First, it informs of the hypothetical effects of GCC and SCCC, but on the base of correlations. Therefore, intervention studies are necessary to test such hypothesis. Second, it does not provide information about the possible causes of differences in the variables assessed, an information that would be useful for taking decisions aimed at modifying such differences. This is also a task for future studies.

Acknowledgements.- This work was carried out with funding from the Spanish Ministry of Economy and Competitiveness (Project EDU2017-89036-P), from the Banco Interamericano de Desarrollo, and from the Ministerio de Educación Pública of Costa Rica. 


\section{References}

Alonso-Tapia, J., \& Rodríguez-Rey, R. (2012). Situaciones de interacción y metas sociales en la adolescencia: desarrollo y validación inicial del cuestionario de metas sociales (CMS). [Interaction situations and social goals in adolescence: Development and initial validation of the Social Goals Questionnaire (SGQ)]. Estudios de Psicología, 33(2), 191-206.

Alonso-Tapia, J., Simón, C., López, N., \& Sandoval, M. (2016). (2016). Cuestionario de Convivencia en el Aula (CCA): un estudio piloto [Classroomcoliving climate questionnaire: A pilot study, Unpublished work. Faculty of Psychology. Universidad Autónoma de Madrid].

Ames, C. (1992). Achievement goals and the classroom motivational climate. In D.H. Schunk, \& J.L. Meece (Eds.), Students perceptions in the classroom (pp.327-348). New York: Lawrence Erlbaum.

Baron, R. A. (1988). Negative effects of destructive criticism: impact on conflict, self-efficacy, and task performance. Journal of Applied Psychology, 73(2), 199.

Clogg, C. C., Petkova, E., \& Haritou, A. (1995). Statistical methods for comparing regression coefficients between models. American Journal of Sociology, 100(5), 1261-1293.

Coleman, J. C., \& Hendry, L. B. (2003). Psicología de la adolescencia. [Psychology of adolescence]. Madrid: Morata.

Dovidio, J. F., Piliavin, J. A., Schroeder, D. A., \& Penner, L. (2006). The social psychology of prosocial behavior. Mahwah, NJ: Lawrence Erlbaum.

Durlak, J. A., Weissberg, R. P., Dymnicki, A. B., Taylor, R. D., \& Schellinger, K. B. (2011). The impact of enhancing students' social and emotional learning: A meta-analysis of school-based universal interventions. Child development, 82(1), 405-432. https://doi.org/10.1111/j.14678624.2010.01564.x

Evans, I.M., Harvey, S. T., Buckley, L., \& Yan, E. (2009). Differentiating classroom climate concepts: Academic, management, and emotional environments. New Zealand Journal of Social Sciences Online, 4, 131-146. http://dx.doi.org/10.1080/1177083X.2009.9522449

Faircloth, B. S., \& Hamm, J. V. (2005). Sense of belonging among high school students representing 4 ethnic groups. Journal of Youth and Adolescence, 34(4), 293-309.

Floyd, K. (2014). Empathic Listening as an Expression of Interpersonal Affection. International Journal of Listening, 28(1), 1-12. http://dx.doi.org/10.1080/10904018.2014.861293

Fornell, C., \& Larcker, D. F. (1981). Evaluating structural equation models with unobservable variables and measurement error. Journal of Marketing Research, 18(1), 39-50. http://dx.doi.org/10.2307/3151312

Furlong, M.J., McGilloway, S., Bywater, T., Hutchings, J., Smith, S.M. Donnelly, M. (2012). Behavioral and cognitive-behavioral group-based parenting programs for early-onset conduct problems in children aged 3 to 12 years (Review). Evidence-Based Child Health 2, 318-692. http://dx.doi.org/10.1002/ebch.1905

Hair, J. F. (2014). A primer on partial least squares structural equations modeling (PLS-SEM). Thousand Oaks, CA: Sage.

Hair, J. F., Black, W. C., Babin, B. J., \& Anderson, R. E. (2010). Multivariate data analysis. Upper Saddle River, NJ: Pearson-Prentice Hall.

Henderlong, J. \& Lepper, M.R. (2002). The Effects of Praise on Children's Intrinsic Motivation: A Review and Synthesis. Psychological Bulletin, 128 (5), 774-795. http://dx.doi.org/10.1037//0033-2909.128.5.774

Jones, S.M. (2011). Supportive listening. International Journal of Listening, 25(1-2), 85-103. http://dx.doi.org/10.1080/10904018.2011.536475

Kristjánsson, K. (2012). Positive psychology and positive education: old wine in new bottles? Educational Psychologist, 47(2), 86-105. http://dx.doi.org/10.1080/00461520.2011.610678

Little, T. D., Cunningham, W. A., Shahar, G., \& Widaman, K. F. (2002). To parcel or not to parcel: Exploring the question, weighing the merits.
Structural Equation Modeling, 9(2),

$151-173$. http://dx.doi.org/10.1207/S15328007SEM0902_1

MacCallum, R. C., Widaman, K. F., Zhang, S., \& Hong, S. (1999). Sample Size in Factor Analysis. Psychological Methods, 4, 8499. http://dx.doi.org/10.1037/1082-989X.4.1.84

McDonald, R. P. (1999). Test theory. A unified treatment. Mahwah, NJ: Erlbaum.

Meece, J. L., Anderman, E. M., \& Anderman, L.H. (2006). Classroom goal structure, student motivation and academic achievement. Annual Review of Psychology, 57, 487-503. http://dx.doi.org/10.1146/annurev.psych.56.091103.070258

Olweus, D. (2001). Peer harassment: A critical analysis and some important issues. In J. Juvonen \& S. Graham (Eds.), Peer harassment in school: The plight of the vulnerable and victimized (pp. 3-20). New York: Guilford Press.

Owen, D.J., Slep, A.M. \& Heyman, R.E. (2012). The effect of Praise, Positive Nonverbal Response, Reprimand, and Negative Nonverbal Response on Child Compliance: A Systematic Review. Clinical Child and $\begin{array}{llll}\text { Family Psychology Review, 15, 364-385. } & \end{array}$ http://dx.doi.org/10.1007/s10567-012-0120-0

Patrick, H., Kaplan, A. \& Ryan, A.M. (2011). Positive classroom motivational environments: Convergence between mastery goal structure and classroom social climate. Journal of Educational Psychology 103(2), 367382. http://dx.doi.org/10.1037/a0023311

Reynolds, A. (2009). Why every student needs critical friends. Educational Leadership, 67(3), 54-57.

Rijsewijk, L., Dijkstra, J. K., Pattiselanno, K., Steglich, C., \& Veenstra, R. (2016). Who helps whom? Investigating the development of adolescent prosocial relationships. Developmental psychology, 52(6), 894. http://dx.doi.org/10.1037/dev0000106

Rodríguez, M. N., \& Ruiz, M. A. (2008). Atenuación de la asimetría y de la curtosis de las puntuaciones observadas mediante transformaciones de variables: Incidencia sobre la estructura factorial. [Attenuation of asymmetry and kurtosis of observed scores through transformations of variables: Incidence on factorial structure]. Psicológica, 29(2), 205-227

Rosa V., Fida R. \& Avallone F. (2011). A Cluster Analysis of High School Students' Styles of "Living-Together" in the Classroom. Procedia Social $\begin{array}{llll}\text { and } \quad \text { Behavioral 380-389. } & \text { Sciences, }\end{array}$ http://dx.doi.org/10.1016/j.sbspro.2011.11.253

Sainio, M., Veenstra, R., Huitsing, G., \& Salmivalli, C. (2010). Victims and their defenders: A dyadic approach. International Journal of Behavioral Development, $35(2)$

144-151. http://dx.doi.org/10.1177/0165025410378068

Shotter, J. (2009). Listening in a Way that Recognizes/Realizes the World of 'the Other'. International Journal of Listening, 23 (1), 21-43. http://dx.doi.org/10.1080/10904010802591904

Sriklaub, K., Wongwanich, S., \& Wiratchai, N. (2015). Development of the classroom climate measurement model. Procedia-Social and Behavioral Sciences, 171, 1353-1359. https://doi.org/10.1016/j.sbspro.2015.01.253

Veenstra, R. \& Dijkstra, J.K. (2011). Transformations in Adolescent Peer Networks. In B. Laursen \& W. A. Collins (eds.) Relationship Pathways: From Adolescence to Young Adulthood (pp. 135-154). New York: Sage.

Voight, A., \& Nation, M. (2016). Practices for Improving Secondary School Climate: A Systematic Review of the Research Literature. American Journal of Community Psychology, 58, 1-2, 174191. http://dx.doi.org/10.1002/ajcp.12074

Walker, J. (2017). Coliving. The Secret Agent Report, Volume 59, 1-17.

Wentzel, K., Russel, S. \& Baker, S. (2014). Peer relationships and positive adjustment at school. In M.J. Furlong, R. Gilman \& E.S. Huebner (Eds.), Handbook of positive psychology in schools. (pp. 260-275). New York: Routledge. 